\title{
EXAMINING COMMUNITY ENGAGEMENT IN HERITAGE CONSERVATION THROUGH GEOPARK EXPERIENCES FROM THE ASIA PACIFIC REGION
}

\author{
Sharina Abdul Halim* and Nor Azizah Ishak
}

Institute for Environment and Development (LESTARI), Universiti Kebangsaan Malaysia, MALAYSIA

*Corresponding author: sharinahalim@ukm.edu.my

Published online: 29 December 2017

To cite this article: Sharina Abdul Halim and Nor Azizah Ishak. 2017. Examining community engagement in heritage conservation through geopark experiences from the Asia Pacific region. Kajian Malaysia 35(Supp.1): 11-38. https://doi.org/10.21315/km2017.35.Supp.1.2

To link to this article: https://doi.org/10.21315/km2017.35.Supp.1.2

\section{ABSTRACT}

Conserving heritage is significant because it reflects and builds local community identities, assists in promoting sustainability and provides sense of place. Geopark concept promotes three main components, namely conservation of heritage resources, provision of tourism infrastructure and local socioeconomic development. Strengthening local community engagement through active participation is pertinent to ensure success of geopark implementation. Engaging local community in heritage conservation collaboratively with other stakeholders is crucial as it has the potential to transform values, practices and overall behaviour towards sustainability. Nevertheless, how local community is engaged has been contested because often the term community engagement used in development process does not fully reflect the extent to which local community is actually able to participate. The main objective of this article is to examine local community engagement in heritage conservation, using geopark experiences from the Asia Pacific region. Analysis of findings will be discussed qualitatively in twofold: firstly, based on results from reviews of secondary data resources and official geopark websites, secondly through survey obtained from 30 participants, from aspiring and UNESCO Global Geoparks member countries, who attended the Asia Pacific Geopark Network (APGN) Regional Course on Geoparks in 2015 and 2017. Heritage conservation, in geopark-based activities, is expressed in various ways, amongst which as a cultural process, such as social interaction of festivals and exhibitions, as well as in natural resource management. In general, main findings indicated there are room for opportunities in geopark-based activities to encourage social learning from local community and stakeholders on heritage 
conservation. It is pertinent that local community are engaged in activities that would strengthen their sense of belonging as local custodians towards promoting sustainable resource utilisation in balancing conservation with development.

Keywords: heritage, conservation, community engagement, geoparks, Asia Pacific

\section{INTRODUCTION}

The notion of heritage has invited many debates among scholars worldwide, from the conceptual and practical to the theoretical sense, that heritage is not easily defined due to its nature of hybridity and complexity (Graham, Ashworth and Tunbridge, 2000; Smith, 2006; Zazu, 2011). One of the ways of defining heritage is placing it within a particular set of cultural or social values given by people and organisations (Laurajane and Akagawa, 2009). These values placed on heritage vary in terms of the reason, level, culture, time and place (Jokiletho, 1999; Graham, Ashworth and Tunbridge, 2000; de la Torre, 2002; Smith, 2006). Conceptualising heritage has also moved from inheritance that an individual received from a deceased ancestor or what a person bequeathed to descendants (Lowenthal, 2005) to include other aspects as Perez, Lopez and Listan (2010) had suggested: "heritage is not only 'historical-artistic' but also encompasses 'objects, environments and phenomena (tangible and intangible), which are the results of both human activities and their interaction with nature."'

The interconnectedness of heritages of nature and culture has important implications for the overall sustainability of heritage resources (Zazu, 2011). As the term heritage itself does not differentiate between natural and cultural, it is safe to assume that whether it is natural or cultural, most importantly now it could also be both. This quantum leap acknowledgement of heritage interwoven dimensions between natural and cultural heritage has a clear implication to how heritage is now conserved and managed. It is becoming more inclusive in the conservation plan and management of heritage that takes into account local perspectives, knowledge and participation in ensuring the success of heritage policies, management and education practices.

Understanding the meaning of heritage would also facilitate the process of conserving it because heritage conservation is tied to the idea of identity, revival and sustainability, amongst many. Thus, conserving heritage is significant because it reflects and builds local community identities, assists in promoting sustainability and provides sense of place (Relph, 1979; Tuan, 1977). These statements reverberate the arguments made by Fong et al. (2012) that "in the case of Asia, as the twentieth century came to a close, clear assertions were being made for a conservation paradigm rooted in philosophies and methodologies appropriate to the 
cultural, aesthetic and political particularities of the region." These deliberations are supported by various charters in ensuring that the integrity and safeguarding of heritage are carried out in a manner that is sensitive to the needs and values of the communities. Amongst many charters, Hoi An Protocols for Best Conservation Practice in Asia illustrates further the dynamics of natural-cultural heritage as (Engelhardt and Rogers, 2009):

In Asia, the physical, human-made components of the heritage are not only inextricably linked to but also arise from the natural geography and environmental setting of their respective cultures and serve as the setting for more intangible expressions of cultural traditions.

Hence, understanding heritage conservation calls for sensitivity to cultural and historical particularities of the region when addressing the issue at various stages of development and management processes: identification, planning, design, implementation, monitoring, and evaluation.

Drawing on this note, heritage conservation in Asia has been said to be incorporated in each respective member countries' national conservation policies. However, it has also been argued that most of the related policies are heavily centralised with limited opportunity for synergy between government, private sectors, NGOs and local communities when addressing the issues of heritage conservation (Fong et al., 2012; Yung and Chan, 2011). Apart from that, the demand to develop in economic terms surpassed the need for conservation and protection, thus hampering any heritage conservation efforts on the ground. The change in scenario is now starting to make way more vigorously, as more countries realised the importance of heritage as part of their national identity and sovereignty. Furthermore, there is an escalating sense of awareness towards heritage conservation by local community through bottom-up, cooperative and comanagement approaches. This awareness is echoed in conservation efforts, such as the UNESCO Global Geoparks; Man and Biosphere Reserve, World Heritage Sites, protected areas and parks, to ensure feasibility and success of heritage conservation by safeguarding that local communities benefit from its establishment and participate in building harmony between people and nature (Anyaoku and Martin, 2003).

Engaging local community in heritage conservation collaboratively with other stakeholders is crucial as it has the potential to transform values, practices and overall behaviour towards sustainability (Sharina, Hood and Mustaffa, 2011a). Nevertheless, the nature and manner of local community engagement in heritage conservation is contested because in reality, often the term community engagement used in development process does not fully reflect the extent to which local community is actually able to participate. 
The main objective of this article is to examine local community engagement in heritage conservation, using the geopark experiences in the Asia Pacific region. This article begins with a discussion on participatory process and background of geopark as well as importance of community engagement. This is followed by an analysis on types of community engagement in heritage conservation based on reviews of secondary materials of selected geoparks in the Asia Pacific region, and on empirical findings obtained through surveys, observation and involvement in geopark-based activities. In the final section, the authors conclude with some suggestions that may help local community and stakeholders' engagement in heritage conservation with special emphasis on active learning as a potential to encourage utilisation of geopark as tool for sustainable regional development.

\section{COMMUNITY PROCESS \\ ENGAGEMENT \\ THROUGH \\ PARTICIPATORY}

The call for community engagement in heritage conservation has gained an increasing momentum particularly in aspects of identity, planning, decisionmaking, gender representations, and cultural attributes. The tangible and intangible composition of cultural heritage provides the platforms for individuals and communities to establish their identity. For instance, in his work on the Kanak villagers of New Caledonia, Horowitz (2008) described their view of conservation as part of reinforcing their identity through preservation of their cultural heritage. This view is also shared by citizens in Macao where the inscription of World Heritage status further enhanced their identity and sense of pride as stewards of the city's important cultural heritage (Chan, 2016). Similarly, observation is also made in Botswana, where the integration of sustainability into cultural heritage resource management was crucial as communities are carriers and immediate custodians of cultural resources in Africa (Keitumetse, 2011).

Encouraging community engagement in heritage conservation is pertinent and has been acknowledged in a wide range of literature (UNESCO, 1972; Head, 2007; Turner and Tomer, 2013). There are many interpretations of levels of participation that would facilitate better understanding on how to engage community in development process, amongst many scholars such as Arnstein (1969), Pretty (1995), White (1996), and Tosun (2000). These interpretations allow researchers to examine participation not only qualitatively but also quantitatively (Chan, 2016). Participation is a dynamic process that has its own limitations. While it is important to ensure local community and stakeholders are engaged throughout the participatory process, prevalent questions still persist on the underlying issues such as who, how and whose terms (White, 1996). 
Participation means different things to different people, depending on the context and background in which participation is applied. Many development agencies are now making explicit statements on what they understand by participation in order to determine appropriate and effective strategy and methodology. There are a range of interpretations on defining participation, such as participation as an active process (Paul, 1987), people are able to genuinely be part in defining issues, making decisions and taking action to achieve change (World Health Organization [WHO], 2002) and increasing people's influence on public policies and programmes to ensuring a more positive impact on their social and economic lives (United Nations, 2013).

Within the context of this article, community is referred to as members of the entire society, including local individuals, government agencies, private sectors, and NGOs, engaging in heritage conservation based on their participation related to selected geoparks, bearing in mind the geographical, social and cultural elements. Research conducted to understand community engagement in heritage conservation through geopark as a tool for sustainable regional development is still in its infancy. One of the reasons for this is because the earlier stages of developing geoparks, particularly in the Asia Pacific region require more problem solving and providing solutions in tackling everyday challenges, for example infrastructure, governance, and education. There were many experiments in implementing geopark concept, as stated by Arima (2016), for instance, when geopark concept was first introduced in Japan in 2008, it brought together geoscientists specializing in regional development and academic communities through many symposia to deliberate on implementing geopark through trial and error hand-in-hand with local communities, governments, researchers and other stakeholders concerning geopark activities.

In managing geoparks, cooperation and participation of local community and various levels of stakeholders are needed, particularly public administration officers, practitioners, academics and NGOs. Understanding how participation is being carried out in geoparks is pertinent to ensure community engagement process is continuously improved as time goes by.

This article will adopt the ladder of participation inspired by Arnstein's model, modified by Chan (2016) to examine local community participation in heritage conservation. The ladder is used as a guide to indicate at which level is the community engagement in heritage conservation for geopark member countries (Figure 1). The ladder of participation has eight steps, starting from education/ promotion, protection/conservation, informing, consultation, advisory, partnership, grassroots-led negotiation, and self-management. A note of clarification, the ladder of participation in this article will be utilised not in the manner of incremental order, rather it is used to gauge qualitative understanding on the various types of community engagement activities for geopark communities that typically occur at different levels. 


\section{Level of Citizen Participation}

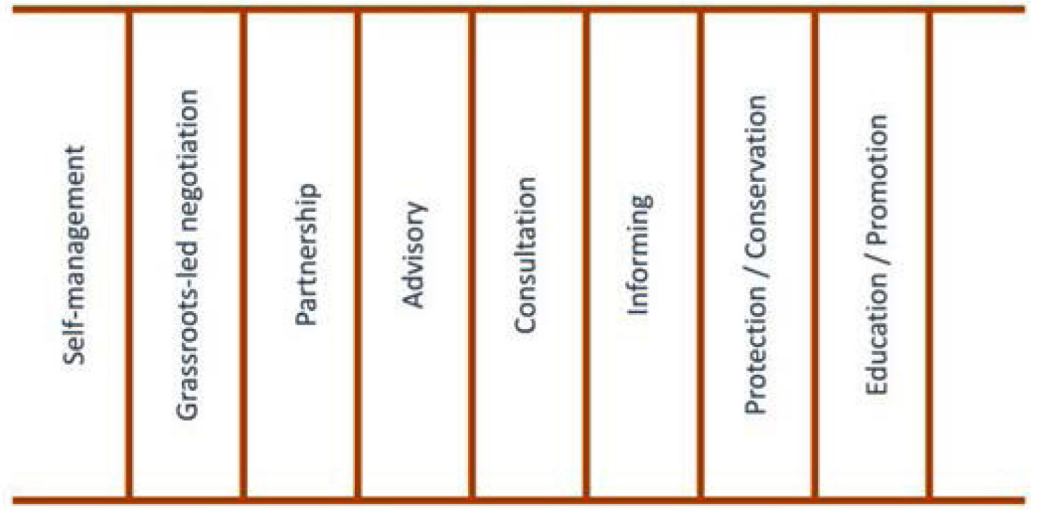

Figure 1: Ladder of participation inspired by Arnstein's model (1969) for managing heritage conservation.

Source: Chan (2016).

\section{GEOPARKS "PROMOTING EARTH HERITAGE, SUSTAINING LOCAL COMMUNITIES"}

Inspirational slogan of "Promoting Earth Heritage, Sustaining Local Communities" sets members of UNESCO Global Geopark to pursue the goals of integrating heritage conservation with development in a sustainable manner. Currently there are 119 UNESCO Global Geoparks (UGGp) in 33 countries, of which 50 UGGp are situated in 7 countries from the Asia Pacific region, namely China (35 UGGp), Malaysia (1 UGGp), Japan (8 UGGp), Korea (2 UGGp), Vietnam (1 UGGp), Indonesia (2 UGGp) and Iran (1 UGGp) (UNESCO, 2017e). In general, UNESCO Global Geoparks can be defined as:

... single, unified geographical areas where sites and landscapes of international geological significance are managed with a holistic concept of protection, education and sustainable development. Their bottomup approach of combining conservation with sustainable development while involving local communities is becoming increasingly popular...

(United Nations Educational, Scientific and Cultural Organization [UNESCO], 2017a). 


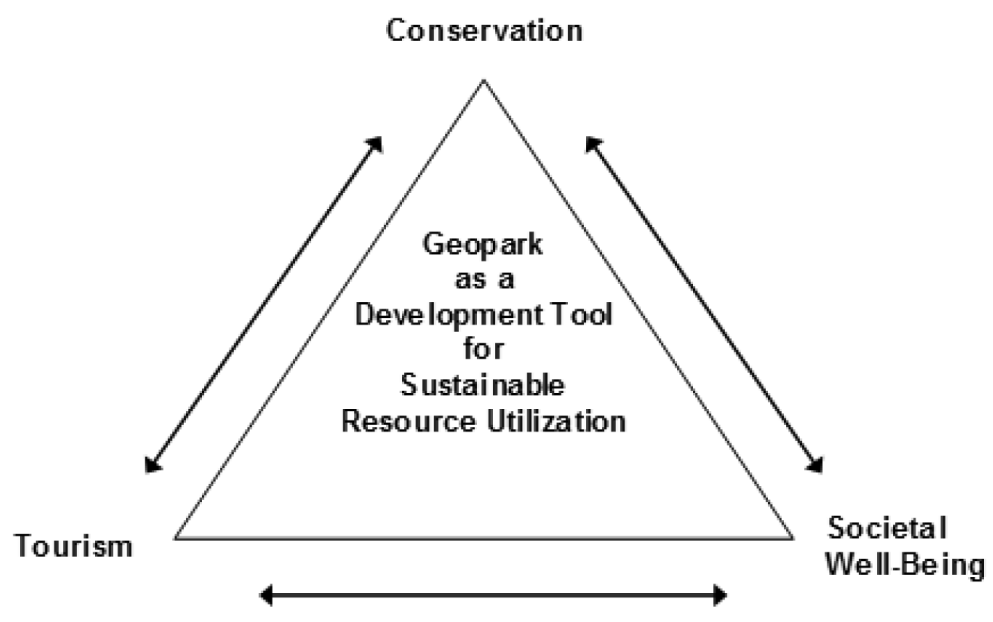

Figure 2: Geopark and its main components.

Source: Ibrahim (2010); Sharina et al. (2011b).

Geopark concept comprises of three main components, namely conservation of heritage, tourism development and societal well-being (Figure 2). Geopark gives emphasis to inclusive elements, particularly in engaging local community participation in conservation efforts to take ownership of resources and locations that are deemed to contribute positively to their better living (McKeever, 2009). In this sense, geoparks could be identified as one process amongst many for achieving the goals of sustainable development. They promote a holistic way of integrating conservation initiatives that take into consideration elements of sustainable resource utilisation, provision of infrastructure for tourism development and uplifting local socio-economic, as well as well-being. The importance of local community engagement is essential in ensuring the success of geopark as emphasised in the document guidelines and criteria for a geopark (Global Geoparks Network [GGN], 2014).

Regarding the criteria, in the document it is written that (Global Geoparks Network [GGN], 2014):

...The establishment of a Geopark should be based on strong community support and local involvement, developed through a "bottomup" process... Success can only be achieved through strong local involvement. The initiative to create a Geopark must therefore come from local communities/authorities with a strong commitment...

...It cannot be repeated often enough that the involvement of the local people is of primary importance for the successful establishment and maintenance of a Geopark... 
Based on the criteria provided, one may conclude that geopark is about empowering the local community to strengthen sense of belonging among them towards promoting sustainable resource utilisation and heritage conservation as local custodianship. The concept of geopark also aspires to address rural development through innovative strategies balancing between conservation and development. One of the examples is through geotourism activities translated to stimulate local engagement in activities leading to prosperity of the local economy and preservation of natural resources (Farsani, Coelho and Costa, 2011). According to the European Geoparks Network (EGN) charter and GGN regulations, all geoparks have to be established in rural areas (Zouros and Martini, 2003); thus, geoparks and geotourism are opportunities for rural development, and they reduce the rates of unemployment and migration in rural areas.

UNESCO Global Geoparks, together with the other two UNESCO site designations Man and Biosphere Reserves and World Heritage Sites, give a complete picture of celebrating Earth heritage while at the same time conserving the world's cultural, biological and geological diversity, and promoting sustainable economic development. While Biosphere Reserves focus on the harmonised management of biological and cultural diversity and World Heritage Sites promote the conservation of natural and cultural sites of outstanding universal value, UNESCO Global Geoparks give international recognition for sites that promote the importance and significance of protecting the Earth's geodiversity through actively engaging with the local communities (UNESCO, 2017b).

It is crucial to ensure stakeholders' participation throughout the cycle of geopark development, from designing, implementing to monitoring geopark programmes and communication. Developing tools of research related to public education and heritage conservation in the context of geopark is necessary to better understand the lives and worlds of the communities. Taking a need analysis of local community and stakeholders into account would ensure effectiveness for any public education work and the best return for programmes and resources that are invested. Further research is needed to track changes to understand the impacts of geopark on community livelihoods. The concept of geopark as a means to consolidate heritage and encourage sustainable socio-economic development has been rigorously promoted in various Asia Pacific Geoparks Network. The success of geopark and its activities can only be achieved through strong local community involvement and commitment of the local authorities. This in turn needs continuous life-long learning through capacity-building, trainings, documentation, archiving and profiling. 


\section{METHOD OF STUDY}

As mentioned earlier there are 50 UNESCO Global Geoparks members from seven countries in the Asia Pacific region. These include China, Indonesia, Malaysia, Japan, Korea, Vietnam and Iran (Figure 3; Table 1). Selected geopark experiences from member countries China, Malaysia, Japan, Korea, Vietnam and Indonesia will be discussed in examining local community engagement in heritage conservation. With this goal in mind, the research design incorporated method of analysing contents of web information sources, mainly official geopark websites, and review of secondary material on geopark, local community, and heritage conservation. Survey was also administered on participants, from aspiring and UNESCO Global Geoparks member countries, who participated in the Asia Pacific Geoparks Network (APGN) Regional Course on Geoparks held in 2015 and 2017 in Langkawi Research Centre, Universiti Kebangsaan Malaysia (UKM). The purpose of this course is to provide capacity-building on geopark development and management especially among members from the Asia Pacific region. Through the APGN Regional Course on Geoparks participants had the opportunity to widen their knowledge on geoparks, and to cooperate with different disciplines and countries.

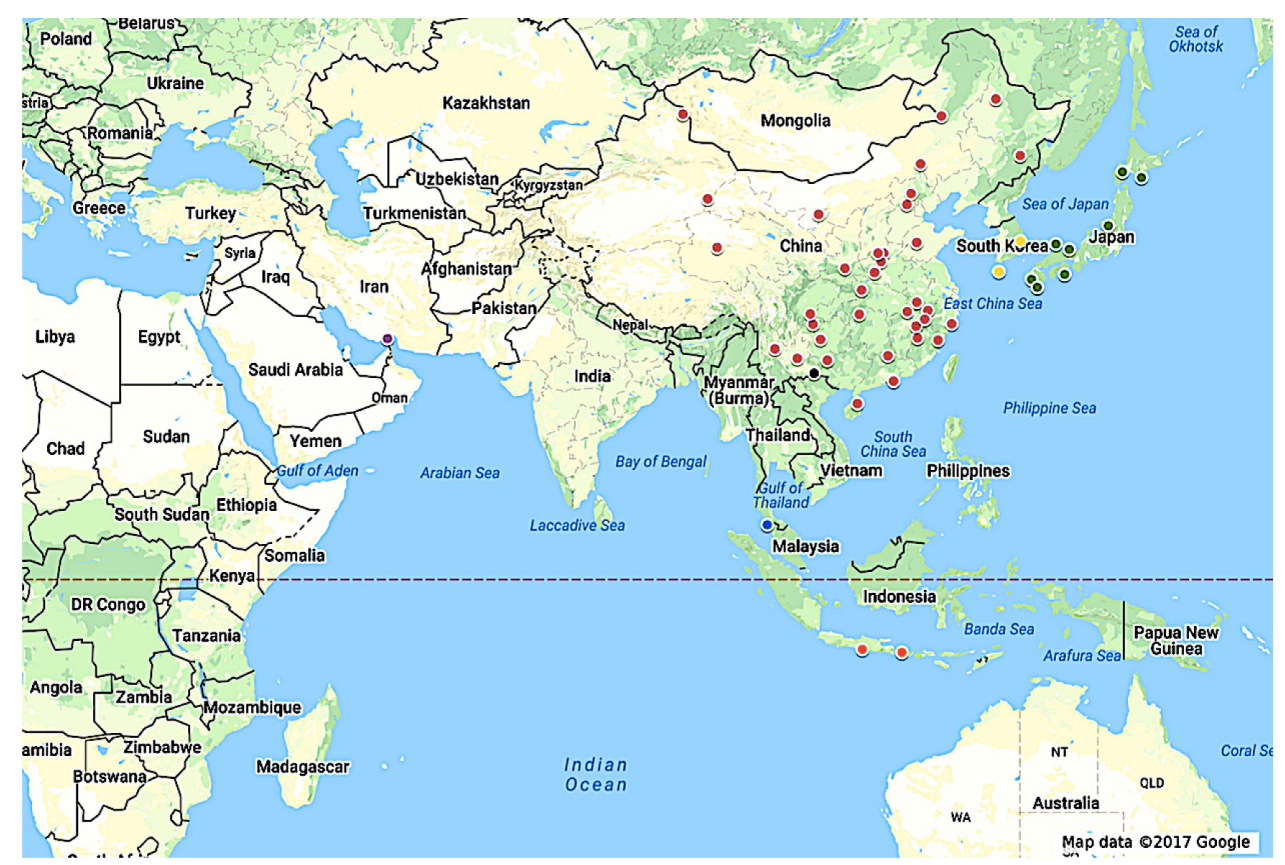

Figure 3: Map distribution of Asia Pacific Global Geoparks.

Source: Google maps (2017); UNESCO (2017e). 
Table 1: Lists of Asia Pacific Geoparks (Updated 2017)

\begin{tabular}{|c|c|}
\hline Asia Pacific Geoparks (Countries) & Geopark \\
\hline China & $\begin{array}{l}\text { Danxiashan UNESCO Global Geopark } \\
\text { Zhangjiajie UNESCO Global Geopark } \\
\text { Yuntaishan UNESCO Global Geopark } \\
\text { Wudalianchi UNESCO Global Geopark } \\
\text { Songshan UNESCO Global Geopark } \\
\text { Shilin UNESCO Global Geopark } \\
\text { Huangshan UNESCO Global Geopark } \\
\text { Lushan UNESCO Global Geopark } \\
\text { Hexigten UNESCO Global Geopark } \\
\text { Taining UNESCO Global Geopark } \\
\text { Xingwen UNESCO Global Geopark } \\
\text { Yandangshan UNESCO Global Geopark } \\
\text { Jingpohu UNESCO Global Geopark } \\
\text { Leiqiong UNESCO Global Geopark } \\
\text { Taishan UNESCO Global Geopark } \\
\text { Wangwushan-Daimeishan UNESCO Global Geopark } \\
\text { Fangshan UNESCO Global Geopark } \\
\text { Funiushan UNESCO Global Geopark } \\
\text { Zigong UNESCO Global Geopark } \\
\text { Longhushan UNESCO Global Geopark } \\
\text { Alxa Desert UNESCO Global Geopark } \\
\text { Qinling Zhongnanshan UNESCO Global Geopark } \\
\text { Ningde UNESCO Global Geopark } \\
\text { Leye Fengshan UNESCO Global Geopark } \\
\text { Tianzhushan UNESCO Global Geopark } \\
\text { Hong Kong UNESCO Global Geopark } \\
\text { Sanqingshan UNESCO Global Geopark } \\
\text { Shennongjia UNESCO Global Geopark } \\
\text { Yanqing UNESCO Global Geopark } \\
\text { Mount Kunlun UNESCO Global Geopark } \\
\text { Dali-Cangshan UNESCO Global Geopark } \\
\text { Dunhuang UNESCO Global Geopark } \\
\text { Zhijindong Cave UNESCO Global Geopark } \\
\text { Arxan UNESCO Global Geopark } \\
\text { Keketuohai UNESCO Global Geopark }\end{array}$ \\
\hline Indonesia & $\begin{array}{l}\text { Batur UNESCO Global Geopark } \\
\text { Gunung Sewu UNESCO Global Geopark }\end{array}$ \\
\hline
\end{tabular}


Table 1: (Continued)

\begin{tabular}{|c|c|}
\hline Asia Pacific Geoparks (Countries) & Geopark \\
\hline \multirow[t]{8}{*}{ Japan } & Itoigawa UNESCO Global Geopark \\
\hline & Unzen Volcanic Area UNESCO Global Geopark \\
\hline & Toya - Usu UNESCO Global Geopark \\
\hline & San'in Kaigan UNESCO Global Geopark \\
\hline & Muroto UNESCO Global Geopark \\
\hline & Oki Islands UNESCO Global Geopark \\
\hline & Aso UNESCO Global Geopark \\
\hline & Mt. Apoi UNESCO Global Geopark \\
\hline \multirow[t]{2}{*}{ Korea } & Jeju UNESCO Global Geopark \\
\hline & Cheongsong UNESCO Global Geopark \\
\hline Malaysia & Langkawi UNESCO Global Geopark \\
\hline Vietnam & Dong Van Karst Plateau UNESCO Global Geopark \\
\hline Iran & Qeshm Island UNESCO Global Geopark \\
\hline
\end{tabular}

Source: UNESCO (2017e).

The authors managed to obtain 16 participants out of 40 total participants that attended the course in 2015, while in 2017, 14 participants out of 47 total participants responded to the survey (Table 2 and Table 3 ). In a cumulative manner for 2015 and 2017, a total of 30 participants answered the survey questions. They generally comprised geologists, geopark managers, staffs and researchers, local authorities/government agencies, tour guides and planners. It is important to gauge the understanding of the participants on community engagement in heritage conservation for geopark development, as most of them are either in the midst of establishing national geopark (Sarawak Delta, Kinabalu World Heritage, and Lembah Kinta, Malaysia; and Mount Popa, Myanmar) or are aspiring UNESCO Global Geoparks (Ciletuh, Toba Caldera and Belitong, Indonesia; and Satun, Thailand), and as such were preparing dossier to submit to Global Geoparks Network for consideration of UNESCO. Views from participants of UNESCO Global Geoparks (Langkawi UGGp; Hong Kong UGGp and Muroto UGGp) are captured and shared on best practices of engaging community in geopark-based activities and heritage conservation. Qualitative approach is used to analyse the findings from secondary and primary sources using content-based analysis. The results of the analysis are divided into three main themes: types of heritage conservation activities; levels of community engagement; benefits and challenges. 
Table 2: Participants who filled in the survey forms during the Asia Pacific Geoparks Network Regional Course on Geopark in $2015(\mathrm{n}=16)$

\begin{tabular}{|c|c|c|c|}
\hline No. & Country & Affiliation & Designation \\
\hline 1. & Malaysia & $\begin{array}{l}\text { Sarawak River Delta (in the process of applying } \\
\text { to become National Geopark) }\end{array}$ & Manager \\
\hline 2. & Malaysia & $\begin{array}{l}\text { Sarawak River Delta (in the process of applying } \\
\text { to become National Geopark) }\end{array}$ & Park Warden \\
\hline 3. & Malaysia & $\begin{array}{l}\text { Sarawak River Delta (in the process of applying } \\
\text { to become National Geopark) }\end{array}$ & Geologist \\
\hline 4. & Malaysia & Lembah Kinta National Geopark & Planner \\
\hline 5. & Malaysia & Lembah Kinta National Geopark & Geologist \\
\hline 6. & Malaysia & Langkawi UNESCO Global Geopark & Assistant Manager \\
\hline 7. & Malaysia & Kinabalu World Heritage Site & Deputy Director \\
\hline 8. & Malaysia & Kinabalu World Heritage Site & Assistant Manager \\
\hline 9. & Thailand & Satun Aspiring UNESCO Global Geopark & Geologist \\
\hline 10. & Thailand & Satun Aspiring UNESCO Global Geopark & Local authority \\
\hline 11. & Thailand & Satun Aspiring UNESCO Global Geopark & Director \\
\hline 12. & Thailand & Satun Aspiring UNESCO Global Geopark & Administrative officer \\
\hline 13. & Indonesia & Ciletuh Aspiring UNESCO Global Geopark & Geologist \\
\hline 14. & Indonesia & Toba Caldera Aspiring UNESCO Global Geopark & Manager \\
\hline 15 . & Iran & Qeshm Aspiring UNESCO Global Geopark & Researcher \\
\hline 16. & $\begin{array}{l}\text { Hong Kong, } \\
\text { China }\end{array}$ & Hong Kong UNESCO Global Geopark & Geologist \\
\hline
\end{tabular}

\section{RESULTS AND DISCUSSION}

In general, three main themes emerged from the secondary and primary data analysis, namely types of heritage conservation activities; levels of community engagement; benefits and challenges.

\section{Types of Heritage Conservation Activities}

The data, from a sample of six official websites (Table 4) of geopark members in the Asia Pacific countries, namely Yandangshan UGGp, Batur UGGp, Mt. Apoi UGGp, Jeju UGGp, Langkawi UGGp, and Dong Van Karst UGGp, were analysed based on activities that promote heritage conservation in line with the geopark concept. It was found that in geopark-based activities, heritage conservation is expressed in various ways such as social interaction of festivals and exhibitions, as well as in natural resource management. It was observed that most geoparks 
Table 3: Participants who filled in the survey forms during the Asia Pacific Geoparks Network Regional Course on Geopark in $2017(\mathrm{n}=14)$

\begin{tabular}{|c|c|c|c|}
\hline No. & Country & Affiliation & Designation \\
\hline 1. & Malaysia & National University of Malaysia (UKM) & Geologist \\
\hline 2. & Malaysia & $\begin{array}{l}\text { Department of Mineral \& Geosciences } \\
\text { (Kedah, Perlis, Pulau Pinang) }\end{array}$ & Director \\
\hline 3. & Malaysia & $\begin{array}{l}\text { Sarawak River Delta (in the process of } \\
\text { applying to become National Geopark) }\end{array}$ & Geologist \\
\hline 4. & Malaysia & Kuching North City Hall, Sarawak & Landscape Architect \\
\hline 5. & Malaysia & Langkawi Tour Guides Association & Tour Guide \\
\hline 6. & Malaysia & Langkawi Tour Guides Association & Tour Guide \\
\hline 7. & Malaysia & Langkawi UNESCO Global Geopark & Advisor \\
\hline 8. & Indonesia & Gunung Sewu UNESCO Global Geopark & Researcher \\
\hline 9. & Indonesia & Belitong Aspiring UNESCO Global Geopark & Local authority \\
\hline 10. & Indonesia & Belitong Aspiring UNESCO Global Geopark & Researcher \\
\hline 11. & Indonesia & Belitong Aspiring UNESCO Global Geopark & Researcher \\
\hline 12. & Indonesia & Belitong Aspiring UNESCO Global Geopark & Geologist \\
\hline 13. & Myanmar & Geological Society & Geologist \\
\hline 14. & Japan & Muroto UNESCO Global Geopark & International Relations Officer \\
\hline
\end{tabular}

are at the stage of education/promotion, protection/conservation, informing and partnership following the ladder of participation shown in Figure 1. As illustrated, Table 4 contains compiled examples of activities from the six sampled geoparks that have direct or indirect contribution to heritage conservation. Local community is engaged in activities that are connected to tourism, education, culture and tradition as well resource utilisation that respond to local and regional characteristics of political and socio-cultural context.

It was found that most official geopark websites are not fully accessible due to language barrier as they are mostly written in the native language. Also, many websites were found to be under maintenance or out of order or that the websites have not been updated regularly. Kohmoto (2011) indicated that the map information on the websites of most geoparks in Asia, are in native language, thus efforts are now on the way to use English language as well, particularly for Japan. The importance of having both native and English languages is that visitors to geoparks are not only domestic but also international. Also, pictures attached in the websites on geoparks have little description and not properly labelled. Similarly, for maps on the geopark website, Kohmoto (2011) noted they lack the necessary information that could potentially increase tourist appreciation and act as educational tool to learn about geoheritage. 


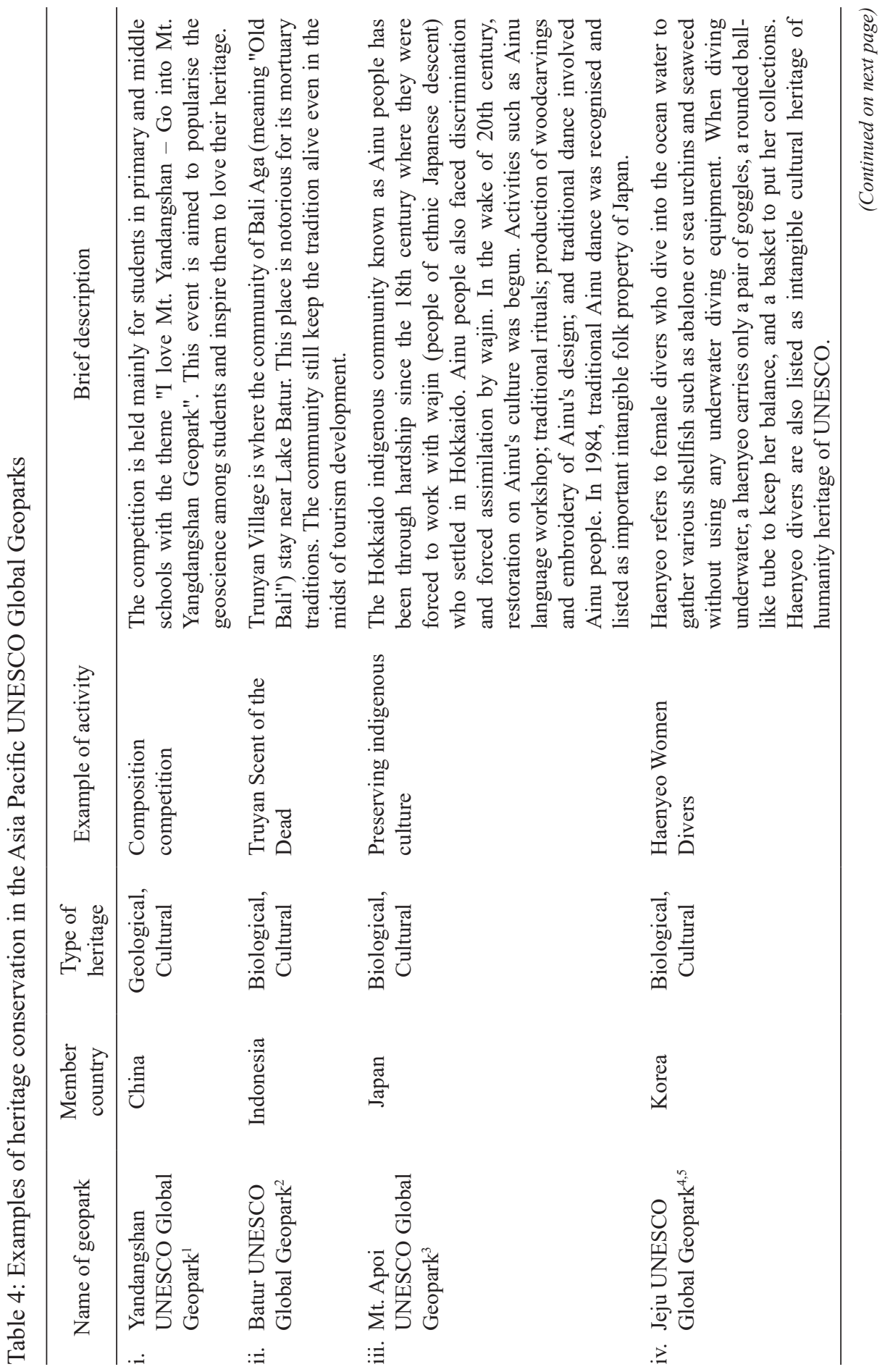




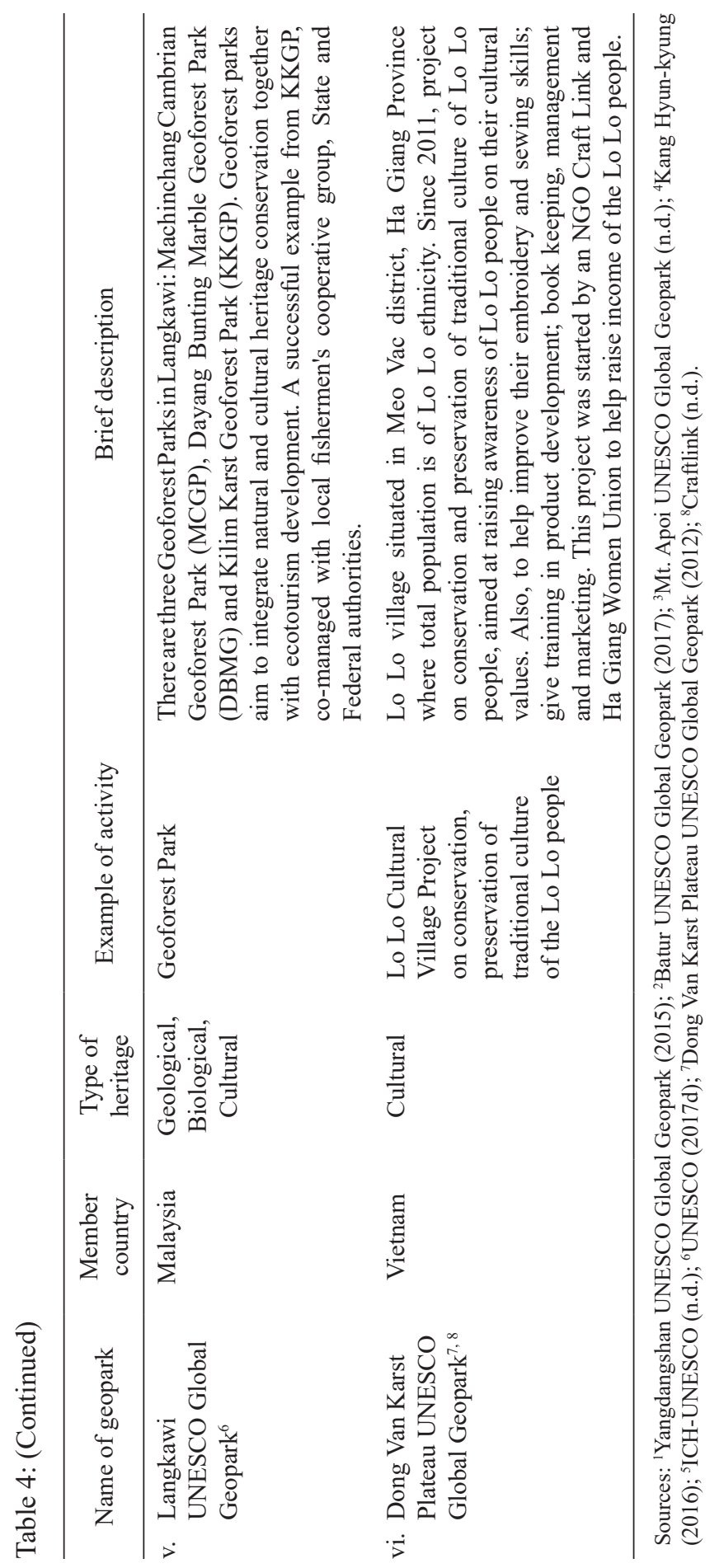


Encouraging responses were obtained from participants when asked about the activities conducted by local communities related to heritage conservation, either in aspiring or UNESCO Global Geoparks. Basically, they indicated that local communities are engaged in various activities that celebrate their local traditions and culture (i.e. food, music, dance, and songs) and linking them with geological and biological heritage resources. As one participant observed:

Many of local community activities, either directly or indirectly, to conserve heritage resources can be linked with geo, bio, cultural resources. For instance, in Langkawi many of the legends and myths on the island are associated with caves and mountains. This combination of knowledge could increase greater appreciation by the locals and tourist towards nature and culture relationship.

A majority of participants suggested that promoting traditional and cultural activities in geoparks can help to revive and keep the local knowledge alive whilst passing it down to the next generation, for instance through homestay programmes, annual "Local Community Heritage Day", and festivals. The idea of heritage conservation in geopark opens up rooms of opportunities to improve socioeconomic conditions of the local community. As mentioned by one participant:

We have the Stegoden-sea cave, local community provide recreational activities at geosites whilst promoting handicrafts, local food and products that are inspired from nature elements in Satun.

\section{Levels of Community Engagement}

Successful local community engagement in geopark-based activities that focus on heritage conservation is achieved through understanding local community background and motivation to conserve heritage resources. Conservation in geopark is based on inclusivity, where a people-centred approach is used to ensure that development and conservation are conducted in a sustainable and equitable manner (Sharina et al., 2011c; Farsani, Coelho and Costa, 2011). As mentioned by a group of participants from UNESCO Global Geoparks during the APGN Regional Course:

Awareness raising and educational programmes for geopark must be conducted for all levels of community at the earlier stage of proposing and developing geopark concept. Because local understanding of geopark varies, thus their willingness to participate are influenced based on their needs and expectations.

Although most local community in Muroto know about geopark, but only $10 \%$ of local community fully understand the concept of geopark. 
Increasing the local communities' sense of belonging towards these resources is pertinent as suggested by Salsela et al. (2015). This is because shared values among local communities form an important component to ensure an effective utilisation of sustainable resources. This can be observed in Kilim Karst Geoforest Park in Langkawi UNESCO Global Geopark. These shared values are fundamental elements to transform local community and stakeholders from being consumptive to appreciative towards natural and cultural resources, as a whole. Thus, understanding levels of community engagement in geopark can be articulated using the ladder of participation as illustrated in Figure 1. Analysis of findings from secondary data reviews shows that local community engagement in heritage conservation can be generally categorised under education, promotion, protection/conservation, consultation and partnership.

\section{Education}

Increasing awareness, knowledge and practice towards heritage conservation in geopark should be conducted for different groups in the community. One of the main groups to be instilled with these values are students as they are agents of change in disseminating information, thus engaging them through practical and experiential learning are crucial (Norzaini et al., 2010). Conserving heritage and promoting geopark could be incorporated into school curricular activities. An example of education-based participation observed is from Yandangshan UNESCO Global Geopark, whereby composition competition was organised, for student in primary and middle schools, with the aim to popularise geoscience and to inspire them to love their heritage (see Table 4). These activities are not limited to schools only, but also to universities, local communities, government agencies, private sector, tourists and NGOs. Continuous knowledge building and sharing on geopark could be transferred through various educational forms and tools, such as training modules, brochures, guide books, geostory, geostudies, workshops, and guiding tours.

Oike (2016) stressed on the importance of learning more than educating in geopark. This is simply because learning means to "learn and study", and active learning cultivates students' varied abilities, including cognition, ethics, social competence, culture and knowledge (Central Council for Education, 2012). The act of learning goes beyond classroom, it incorporates learning from local residents along with students and teachers. Yuhora, Yamashita and Takahashi (2016) report on educational programs in Muroto High School in the Muroto UNESCO Global Geopark. They emphasised on "geographical perspective" in their educational programs, such as in geo-studies. The learning process is inculcated from local residents, with the support from teachers, to students. For instance, students in the music curriculum study local traditional performing arts and try to transmit 
information about the art themselves. Yuhora, Yamashita and Takahashi (2016) stated that, although faced with challenges, this form of learning produce educational benefit not only for students but also local residents.

\section{Promotion}

In the sampled geopark websites reviewed (Table 4), the coverage on promotion showed that the community engagement activities are connected to tourism, resource utilisation, and heritage for the purpose of socio-economic development and conservation. The pictures in the geopark websites indicated mainly outdoor activities and recreation, homegrown food and delicacies, cultural heritage (handicrafts and museums), and local traditions as well as a way of life. It is evident that geoparks play an important role in the development of local economy of their territories (Farsani, Coelho and Costa, 2011; Hadian, Ayu and Krishna, 2016; Takenouchi, 2011; Ong and Sharina, 2011). Conservation of heritage resources in geoparks is carried out together with development of socio-economic and sociocultural dimensions through collaborating with locally based small-and-medium enterprises to develop products and new services. Balancing conservation with development in geopark is crucial to ensure local community and stakeholders in geopark would recognise and appreciate geoheritage and engage in its cultural activities, arts and economic regeneration (Hose, 2007).

Geopark provides the platform to strengthen connections with local community by involving them in the establishment and maintenance of a geopark and by revitalising local economy through tourism based on local resources, for instance geoproducts, and geotourism (Woo et al., 2013). As geoparks are situated in rural areas, geoparks stimulate local policies in order to invigorate rural regeneration, provide more opportunities in rural areas, reduce unemployment rate and migration through engaging local communities in innovative geopark-based activities (Farsani, Coelho and Costa, 2011). A study conducted by Ohno (2011) on the status of tourism promotion and its sustainability in the Unzen Volcanic Area UNESCO Global Geopark revealed that geotourism in the form of geotours and geostories is the key in connecting geoparks to sustainable tourism and promoting regional development. Geostories combine knowledge related to landforms and landscape with local history, culture, and traditions. It is important to present these stories to the residents and tourists in a comprehensible manner. Therefore, training guides in geoparks is a major factor for successfully achieving regional promotion. The use of geostories was also shared by one of the participants from Hong Kong UNESCO Global Geopark: 
Increasing awareness through legend and story-telling by villagers or ancestors helps to promote geopark and conserve heritage. Geopark authorities should carry out outreach programmes to promote the real concept of geopark and emphasise the benefits to local community.

\section{Conservation}

Several geopark experiences from Jeju UNESCO Global Geopark, Batur UNESCO Global Geopark, Mt. Apoi UNESCO Global Geopark and Dong Van Karst Plateau UNESCO Global Geopark (Table 4) were indicative of the relationship between nature and culture conservation. Local community is actively engaged in conservation to ensure their heritage is being protected for the present and future generation. Having the geopark status further enhanced the need to strengthen their identity as well as to share and educate the world about their communities through various ways that combines conservation with socio-economic development. Hadian, Ayu and Krishna (2016) contend that geotourism can help travellers to enjoy more of the "local taste" at the destination. The local taste is the result of synchronisation between tourism policy and the local community life including their culture, habits, traditional products and socio-economic systems. This form of tourism can improve the life of local communities without causing the loss or impairment of traditional system and values (Farsani, Coelho and Costa, 2012; Harmon and Viles, 2013).

The challenge to integrate nature and culture in conservation has been widely debated (Eghenter, 2008; Hood and Bettinger, 2008; Steven, 1997). Geoparks aspire to address its inclusivity approach. Among the earliest geoparks that understood the importance of this integrated heritage conservation was stated to be Shilin UNESCO Global Geopark, established in 2004 (Partin, Robinson and Meade, 2006). Another unique aspect of the Shilin UNESCO Global Geopark is the emphasis on training and educating its park employees. Each year, tour guides must pass a compulsory exam about the geology and geography of the park and the local ethnic history. At least one specialist is trained by UNESCO, who then serves as a trainer for other park employees. Through observation Partin, Robinson and Meade (2006), noted that Shilin UNESCO Global Geopark manages to incorporate the key aspects of education, protection, and development into not only a site of geological heritage but also of cultural heritage.

However, within the context of conservation, there are still many challenges faced by geoparks in the Asia Pacific region mainly finding the best way to harmonise conservation and development. When posed to participants "how are the official processes of decision-making in conserving and maintaining your geopark/aspiring geopark?" the responses obtained from participants echo similar concern regarding laws and regulations in protecting and proper usage of heritage 
resources, and educating the authorities and stakeholders to co-manage geopark effectively. As mentioned by a participant from UNESCO Global Geoparks:

It is challenging managing geoforest park due to multiple interests and require participatory approach. It helps that most of the area are located in protected area, such as permanent forest reserve, wildlife protection area, that have existing act like Forestry Act to conserve and maintain the site.

This viewpoint was reinforced by another participant from an aspiring geopark, who stated:

Conserving and maintaining geopark must have management plan that are in line with the existing local plans and special area plans.

Thus, balancing conservation with development in geopark implies a shift from the philosophy of management to empowering local participation by utilising the co-management approach. Through this approach private sectors, local authorities, government agencies, local community and other stakeholders work collectively towards sustainability.

\section{Consultation}

Earlier on, the writers discussed the potential of active learning in encouraging participation among various stakeholders. Active learning is also part of the transformative learning (Mezirow, 1991). As learners develop greater awareness of themselves and deeper understanding of their own experience, their desire to grow and develop increases. Such knowledge is personal and, therefore, emancipatory. Mezirow conceives of constructions of reality or perspectives as being intensely individual and unique for each person (Jarvis, 1988). Consultation process in developing geoparks is critical to move towards empowerment among local community and stakeholders together with improving government's support. In Samani town, Mt. Apoi UNESCO Global Geopark, town hall meeting was held to discuss the "future for Samani". It was a fruitful exercise that gathered various people from all walks of life. Participants of the town hall meeting gave and shared their ideas on the future for Samani and came up with specific actions, in which they agreed that conservation and industrial development can be achieved cohesively (Dublin, Bancheva and Freitag, 2013). Town hall meetings with citizen involvement are part of the consultation process that could be an important strategic planning instrument (Dublin, Bancheva and Freitag, 2013). 


\section{Partnership}

One intiative in Jeju UNESCO Global Geopark taken by the local community is the development of the Jeju Olle walking/cycling track that runs around the southern coastline from the Seonsan Ilchulbong to the Suweolbong geosites (Woo et al., 2013). Although initially the initiative was undertaken without the geopark concept in mind, it nevertheless forms an excellent pattern for future activities of its kind. Jeju Island gained its UNESCO Global Geopark status in 2010 and benefited through this initiative which has attracted local residents by establishing partnerships between local village and production companies and by providing an Internet website for selling local agricultural product.

The synergy of all actors involved in geopark is crucial in order to strengthen commitment and participation. As one of the participants from aspiring Toba Caldera shared:

All or every single piece of land in Toba Caldera geopark belong to the groups of community members. They owned land collectively. Thus, geopark will be successful if fully engaged with the local community and the benefits of geopark is shared amongst them.

In Langkawi UNESCO Global Geopark, the formation of communitybased fisheries resource management or Komuniti Pengurusan Sumber Perikanan (KPSP) was a significant attempt by the Federal Government to emphasise the value of local involvement in natural resource management. It acknowledges the importance of ensuring a continuous learning process for fisher folks in managing their resources to ensure sustainable livelihoods for their community (Sharina et al., 2011c). This paradigm shift is required not only from government agencies, but also from the community members themselves. This means that the role of the government should shift from one of command-and-control to one of service provider, facilitator and partner with the community (Hildebrand, 1997: 2). In KPSP Kilim Geoforest Park, due to an influx of tourist arrivals for eco/geotourism activities, alternative employment for many of its members was available, from traditional fishermen to tour guides and boat operators, resulting in a net increase in income and quality of life.

\section{Benefits and Challenges}

Geoparks are said to have brought various innovative opportunities that facilitate rural socio-economic development through geotourism whilst conserving heritage resources in a sustainable manner (Farsani et al., 2014). However, the challenges in realising geopark aspiration are experienced by many geoparks in the Asia Pacific 
region at various levels, such as institutional, structural and operational. Koizumi and Chakraborty (2015) succinctly explained the challenge in geopark "...as there is a growing tendency to 'objectify' the earth's heritage and utilise it as a selling point...". This tendency has implication not only towards geoheritage resources but also related to ecosystems and culture. This is a challenge particularly for the Asia Pacific region, where geoparks are widely seen as a tool for revitalising local economies (Kikuchi et al., 2011; Ibrahim, 2004).

When the managers and staffs of aspiring or UNESCO Global Geoparks were asked about their views on the challenges in promoting heritage conservation in geopark, they commented:

Most local community members have different levels of educational background, we need creative ways to deliver the messages.

The challenge is to convince local community and stakeholders that geopark development is closely related to their lives and has direct socio-economic impact.

I don't know how to say this, but if we don't provide carrots, they (local community) are not going to participate.

Continuous efforts to increase awareness, knowledge and understanding towards heritage conservation in geoparks must be given serious consideration by various stakeholders. Education and learning tools should be incorporated in geopark-based activities to impart the importance of these sites that have been recognised for their Outstanding Universal Values (OUVs). Amidst all of the challenges in implementing geopark, when the participants of the APGN Regional Geopark Course were asked about geopark role in heritage conservation and community development, a majority of the participants agreed that:

Geopark instils sense of pride and love among the people. It is a holistic approach to bring the community together.

Geopark and community development has a symbiotic relationship, which benefits both parties, if we can do it in a sustainable manner.

Sustainability action on the ground, sprouting local, smaller and indigenous entrepreneurship. Raising the quality life and local community livelihoods.

Thus, making sense of geopark to local community and stakeholder would facilitate greater support and participation towards creating a win-win situation of promoting local economic growth whilst maintaining sustainable development of geopark itself (Han et al., 2017). 


\section{CONCLUSION}

One of the ways to ensure improved and increased local community's appreciation towards geopark and heritage conservation is through understanding their attitudes towards needs and aspirations, background and culture. Local communities' benefits and opportunities in geopark development are often related to socioeconomic terms and sense of belonging. Thus, it is important to provide platform for discussions in order to stimulate interactive sessions and optimise the potential of educational and outreach activities towards sustainable resource utilisation and conservation of heritage resources. As the need for conservation, education and outreach grows, systematic planning is critical in meeting the goals of public education. It is also crucial to pursue continuous research to track the changes and impacts of geoparks on community's livelihoods. All levels of stakeholders and local communities, in particular community leaders, youths, women and gender groups, should be motivated to participate in geopark current and future activities. This motivation is necessary to empower them to increase their sense of belonging towards heritage value and conservation in a sustainable manner for the benefit of present and future generation.

\section{ACKNOWLEDGEMENTS}

The writers would like to express their heartfelt gratitude to Institute for Environment and Development (LESTARI), Universiti Kebangsaan Malaysia (UKM) and the Asia Pacific Geoparks Network (APGN) for giving them the opportunity to participate in various APGN symposium, outreach and network activities. Special thanks also to Kementerian Pengajian Tinggi (KPT) and UKM for the research grants FRGS/1/2014/STWN09/UKM/02/1; and Langkawi Research Centre (PPL UKM) AP-2014-007.

\section{REFERENCES}

Anyaoku, C. E. and C. Martin. 2003. Parks and participation. UNEP Our Planet 14(2): 14-15.

Arima, T. 2016. Overview: The educational capabilities of geoparks: From education to learning. Journal of Geography (Chigaku Zasshi) 125(6): 775-778. https://doi. org/10.5026/jgeography.125.775.

Arnstein, S. R. 1969. A ladder of citizen participation. Journal of the American Institute of Planners 35(4): 216-224. https://doi.org/10.1080/01944366908977225.

Batur UNESCO Global Geopark. 2017. Trunyan. http://www.indonesia-tourism.com/bali/ trunyan.html (accessed 24 April 2017). 
. n.d. Warisan budaya: Desa Trunyan. https://www.baturglobalgeopark.com/index. php/profil/16/Warisan-Budaya.htm (accessed 9 October 2017).

Central Council for Education. 2012. Summary of report: Towards a qualitative transformation of university education for building a new future - universities fostering lifelong learning and the ability to think independently and proactively. http://www.mext.go.jp/en/publication/report/title01/detail01/_icsFiles/ afieldfile/2016/12/06/1380275_001.pdf (accessed 26 September 2017).

Chan, P. Y. 2016. Community participation in heritage management: A case in Macau. Master diss., New York: Columbia University.

Craftlink. n.d. Lolo in Meo Vac, Ha Giang. http://www.craftlink.com.vn/projects/ethnicgroups/Lolo-Meo-vac-Hagiang.html (accessed 24 April 2017).

De la Torre, M. 2002. Assessing the values of cultural heritage. Los Angeles: The Getty Conservation Trust.

Dong Van Karst Plateau UNESCO Global Geopark. 2012. Lo Lo cultural village, Meo Vac district. http://dongvangeopark.com/lang-van-hoa-du-lich-lo-lo-chai-xa-lung-cuhuyen-dong-van/?lang=en (accessed 24 April 2017).

Dublin, D. R., A. I. Bancheva and A. Freitag. 2013. Local initiatives for sustainable development in rural Hokkaido: A case study of Samani. Geography, Environment, Sustainability 6(2): 72-79. https://doi.org/10.24057/2071-9388-2013-6-2-72-79.

Dusar, M., J. Masschelein, O. Batelaan, R. Swennen, D. Wildemeersch and T. V. Tran. 2011. The making of Dong Van Karst Plateau geopark: Tracing its origin through the evolution of a cooperation project on karst research. The Journal of Geology Series B (37-38): 60-69.

Eghenter, C. 2008. Whose heart of Borneo? Critical issues in building constituencies for equitable conservation. In Reflections on the heart of Borneo, eds. G. A. Persoon and M. Osseweijer. Wageningen, the Netherlands: Tropenbos International.

Engelhardt, R. A. and P. R. Rogers. 2009. Hoi An Protocols for best conservation practice in Asia: Professional guidelines for assuring and preserving the authenticity of heritage sites in the context of the cultures of Asia. Bangkok: UNESCO. http:// unesdoc.unesco.org/images/0018/001826/182617e.pdf (accessed 26 September 2017).

Farsani, N. T., C. Coelho and C. Costa. 2012. Geotourism and geoparks as gateways to socio-cultural sustainability in Qeshm Rural Areas, Iran. Asia Pacific Journal of Tourism Research 17(1): 30-48. https://doi.org/10.1080/10941665.2011.610145.

2011. Geotourism and geoparks as novel strategies for socio-economic development in rural areas. International Journal of Tourism Research 13(1): 68-81. https://doi.org/10.1002/jtr.800.

Farsani, N. T., C. O. A. Coelho, C. M. M. Costa and A. Amrikazemi. 2014. Geo-knowledge management and geoconservation via geoparks and geotourism. Geoheritage 6(3): 185-192. https://doi.org/10.1007/s12371-014-0099-7.

Fong, K., T. Winter, H. U. Rii, P. Khanjanusthiti and A. Tandon. 2012. Same but different? Roundtable discussion on the philosophies, methodologies, and practicalities of conserving cultural heritage in Asia. In The Routledge Handbook of Heritage in Asia, eds. P. Daly and T. Winter. Abingdon: Routledge. 
Global Geoparks Network (GGN). 2014. Guidelines and criteria for national geoparks seeking UNESCO's assistance to join the Global Geoparks Network $(G G N)$ (January 2014). France: European Geoparks Network. http://www. europeangeoparks.org/wp-content/uploads/2012/03/Geoparks_Guidelines_ Jan2014.pdf (accessed 26 September 2017).

Google Maps. 2017. Map distribution of Asia Pacific global geoparks. Unpublished.

Graham, G., G. J. Ashworth and J. E. Tunbridge. 2000. Geography of heritage: Power, culture and economy. London: Arnold Press.

Hadian Mohamad Sapari, Ayu Krishna Yuliwati and Krishna Nur Pribadi. 2016. Increasing community environmental awareness through geodiversity conservation activities at Ciletuh, Sukabumi, West Java. Journal of Environmental Management and Tourism 7(2): 334-337.

Han, J., F. Wu, M. Tian and W. Li. 2017. From geopark to sustainable development: Heritage conservation and geotourism promotion in the Huangshan UNESCO Global Geopark (China). Geoheritage 1-13.

Harmon, B. and H. Viles. 2013. Beyond geomorphosites: Trade-offs, optimization, and networking in heritage landscapes. Environment Systems and Decisions 33(2): 272-285. https://doi.org/10.1007/s10669-013-9448-3.

Head, B. W. 2007. Community engagement: Participation on whose terms? Australian Journal of Political Science 42(3): 441-454.

Hildebrand, L. P. 1997. Introduction to the special issue on community-based coastal management. Ocean and Coastal Management 36: 1-9.

Hood Salleh and K. A. Bettinger. 2008. Indigenous peoples and parks in Malaysia: Issues and questions. In Biodiversity and human livelihoods in protected areas: Case studies from the Malay Archipelago, eds. N. S. Sodhi, G. Acciaioli, M. Erb and K. Tan, 289-310. Cambridge: Cambridge University Press.

Horowitz, L. 2008. Destroying god's creation or using what he provided? Cultural models of a mining project in New Caledonia. Human Organization 67(3): 292-306. https://doi.org/10.17730/humo.67.3.a087g071782371q6.

Hose, T. A. 2007. Geoconservation versus geo-exploitation and the emergence of modern geotourism. In Abstracts Volume Geo-Pomerania Szczecin 2007 Joint Meeting PTG-DGG: Geology cross-bordering the Western and Eastern European platform, eds. H. G. Röhling, Ch. Breitkreuz, Th. Duda, W. Stackebrandt, A. Witkowski, and O. Uhlmann. Szczecin: University of Szczecin.

Ibrahim Komoo. 2010. Geopark sebagai peraga pembangunan lestari wilayah. Akademika 80 (Disember): 9-18.

2004. Geoheritage conservation and its potential for geopark development in AsiaOceania. In Warisan geologi Malaysia (trans. Geological heritage of Malaysia), eds. Mohd Shafeea Leman and Ibrahim Komoo. Bangi: LESTARI, UKM.

ICH-UNESCO. n.d. Culture of Jeju Haenyeo (women divers) Republic of Korea: Inscribed in 2016 (11.COM) on the Representative list of the intangible cultural heritage of humanity. http://www.unesco.org/culture/ich/en/RL/culture-of-jeju-haenyeowomen-divers-01068 (accessed 24 April 2017).

Jarvis, P. 1988. Adult and continuing education: Theory and practice. London: Routledge. Jokiletho, J. 1999. History of architectural conservation. Butterworth: Heinemann. 
Kang Hyun-kyung. 2016. 'Haenyo' inscribed on UNESCO cultural heritage list. The Korea Times, 1 December. http://www.koreatimes.co.kr/www/news/ nation/2016/12/116_219276.html (accessed 24 April 2017).

Keitumetse, S. O. 2011. Sustainable development and cultural heritage management in Botswana: Towards sustainable communities. Sustainable Development 19(1): 49-59. https://doi.org/10.1002/sd.419.

Kikuchi, T., S. Iwata, M. Watanabe, J. Matsumoto and H. Koide. 2011. Preface for the special issue on "Geoparks and regional development". Journal of Geography (Chigaku Zasshi). 120: 729-732.

Kohmoto, D. 2011. Geotourism and the concept of "regional diversity" born from geography: Sharing viewpoints of "geo" to build sustainable regional societies. Journal of Geography (Chigaku Zasshi) 120: 775-785.

Koizumi, T. and A. Chakraborty. 2015. Geoecotourism and environmental conservation education: Insights from Japan. GeoJournal 81(5): 737-750.

Laurajane, S. and N. Akagawa, eds. 2009. Intangible heritage. London and New York: Routledge.

Lowenthal, D. 2005. Natural and cultural heritage. International Journal of Heritage Studies (11)1: 81-92.

McKeever, P. J. 2009. The UNESCO global network of national geoparks: Geological heritage and sustainability. LESTARI Public Lecture Series No. 7. Selangor: LESTARI, UKM.

Mezirow, J. 1991. Transformative dimensions of adult learning. San Francisco: JosseyBass Publishers.

Mohd Shafeea Leman, Kamarulzaman Abdul Ghani, Ibrahim Komoo and Norhayati Ahmad, eds. 2007. Langkawi geopark. Selangor: LESTARI, UKM.

Mt. Apoi UNESCO Global Geopark. n.d. The hardships of the Ainu people and their restoration as an indigenous community. http://www.apoi-geopark.jp/english/ apoi/theme_c2.html (accessed 24 April 2017).

Norzaini Azman, Ibrahim Komoo, Sharina Abdul Halim and Ruslin Amir. 2010. Pendidikan awam untuk pemuliharaan warisan: Kajian kes Langkawi Geopark. Akademika. 80: 85-94.

Norzaini Azman, Sharina Abdul Halim and Ibrahim Komoo. 2009. Integrated public education for heritage conservation: A case for Langkawi Global Geopark. In RIMBA: Sustainable forest livelihoods in Malaysia and Australia, eds. G. Ainsworth and S. Garnett. Bangi: Penerbit LESTARI UKM.

Ohno, M. 2011. Local sustainable development using geoheritage: Geostory of the Unzen Volcanic Area Geopark. Journal of Geography (Chigaku Zasshi) 120(5): 834845. https://doi.org/10.5026/jgeography.120.834.

Oike, K. 2016. Learning from Japanese geoparks. Journal of Geography (Chigaku Zasshi). 125(6): 785-794.

Ong, P. L. and Sharina Abdul Halim. 2011. Planning for heritage tourism: The case of Langkawi Geopark. Planning Malaysia 1(Special issue): 121-144.

Partin, C., S. Robinson and B. Meade. 2006. Geological heritage in Chinese parks: Balancing protection and development. Focus on Geography 49(3): 10-16. https://doi.org/10.1111/j.1949-8535.2006.tb00168.x. 
Paul, S. 1987. Community participation in development projects - The World Bank experience. World Bank discussion paper. Washington: The World Bank.

Perez, R. J., J. M. Lopez and D. M. F. Listan. 2010. Heritage education: Exploring the conceptions of teachers and administrators from the perspective experimental and social science teaching. Teaching and Teacher Education 26: 1319-1331.

Pretty, J. N. 1995. Participatory learning for sustainable agriculture. World Development 23(8): 1247-1263. https://doi.org/10.1016/0305-750X(95)00046-F.

Relph, E. 1979. Place and placelessness. London: Pion.

Salsela Saidin, Norzaini Azman, Ibrahim Komoo, Sharina Abdul Halim, Stacey, N. and Izurieta, A. 2015. Pengukuhan nilai sepunya melalui strategi pendidikan awam: Kajian kes Kilim Geoforest Park, Malaysia. Kajian Malaysia 33(2): 83-115.

Sharina Abdul Halim, Hood Salleh and Mustaffa Omar. 2011a. Engaging the local community in participatory resource management through learning: The experience from Langkawi Island, Malaysia. Kajian Malaysia 9(Supp.1): 125139.

Sharina Abdul Halim, Ibrahim Komoo, Hood Salleh and Mustaffa Omar. 2011b. The geopark as a potential tool for alleviating community marginality. Shima: The International Journal of Research into Island Cultures 5(1): 94-113.

Sharina Abdul Halim, P. L. Ong, Nurhafizah Yussof and C. S. Lim. 2011c. Participation towards heritage conservation: Case of a fishing community in Langkawi Geopark. Planning Malaysia 1(Special issues): 185-196.

Smith, L. 2006. Uses of heritage. London and New York: Routledge.

Steven, S. 1997. Conservation through cultural survival: Indigenous peoples and protected areas. Washington, DC: Island Press.

Takenouchi, K. 2011. Regional development in Itoigawa Geopark. Journal of Geography (Chigaku Zasshi) 120: 819-833.

Tosun, C. 2000. Limits to community participation in the tourism development process in developing countries. Tourism Management 21: 613-633.

Tuan, Y. F. 1977. Space and place: The perspective of experience. London: University of Minnesota Press.

Turner, M. and T. Tomer. 2013. Community participation and the tangible and intangible values of urban heritage. Heritage and Society 6(2): 185-198. https://doi.org/10. 1179/2159032X13Z.00000000013.

United Nations Educational, Scientific and Cultural Organization (UNESCO). 2017a. UNESCO global geoparks. http://www.unesco.org/new/en/natural-sciences/ environment/earth-sciences/unesco-global-geoparks/ (accessed 26 September 2017).

. 2017b. UNESCO global geoparks, biosphere reserves and world heritage sites: A complete picture. http://www.unesco.org/new/en/natural-sciences/environment/ earth-sciences/unesco-global-geoparks/frequently-asked-questions/differencebetween-unesco-global-geoparks-biosphere-reserves-and-world-heritage-sites/ (accessed 26 September 2017). 
. 2017c. Gunung Sewu UNESCO global geopark (Indonesia): Sustaining local communities. http://www.unesco.org/new/en/natural-sciences/environment/ earth-sciences/unesco-global-geoparks/list-of-unesco-global-geoparks/ indonesia/gunung-sewu/ (accessed 24 April 2017).

. 2017d. Langkawi UNESCO global geopark (Malaysia): Sustaining local communities. http://www.unesco.org/new/en/natural-sciences/environment/ earth-sciences/unesco-global-geoparks/list-of-unesco-global-geoparks/malaysia/ langkawi/ (accessed 24 April 2017).

. 2017e. List of UNESCO global geoparks. http://www.unesco.org/new/en/naturalsciences/environment/earth-sciences/unesco-global-geoparks/list-of-unescoglobal-geoparks/ (accessed 24 April 2017).

.1972. International convention on the protection of world cultural and natural heritage. Paris: UNESCO.

United Nations. 2013. Citizen engagement and the post-2015 development agenda Report of the expert group meeting. New York: United Nations. http://www. un.org/esa/socdev/egms/docs/2013/EmpowermentPolicies/UNESCWA_CitizenEngagement_Post-2015.pdf (accessed 26 September 2017).

White, S. C. 1996. Depoliticising development: The uses and abuses of participation. Journal Development in Practice 6(1): 6-15. https://doi.org/10.1080/09614529 61000157564.

World Health Organization (WHO). 2002. Community participation in local health and sustainable development - approaches and techniques. Copenhagen: WHO Regional Office for Europe. http://www.euro.who.int/_data/assets/pdf_ file/0013/101065/E78652.pdf (accessed 26 September 2017).

Woo, S. K., Y. K. Sohn, U. S. Ahn, S. H. Yoon and A. Spate. 2013. Jeju Island Geopark - A volcanic wonder of Korea. Berlin: Springer.

Yangdangshan UNESCO Global Geopark. 2015. Composition competition with the theme of "I Love Mt Yandang" held by Mt. Yandangshan Geopark. http://www.yds-en. com/?p=1538 (accessed 24 April 2017).

Yuhora, K., S. Yamashita and S. Takahashi. 2016. Geopark education adopts a geographical viewpoint at Muroto Senior High School. Journal of Geography (Chigaku Zasshi) 125: 813-829.

Yung, E. H. K and E. H. W. Chan. 2011. Problem issues of public participation in built-heritage conservation: Two controversial cases in Hong Kong. Habitat International 35: 457-466.

Zazu, C. 2011. Heritage - A conceptually evolving and dissonant phenomenon: Implications for heritage management and education practices in post-colonial Southern Africa. Southern African Journal of Environmental Education 28: 135-143.

Zouros, N. and G. Martini. 2003. Introduction to the European Geoparks Network. Paper presented at Proceeding of 2nd Inter. Symposium of Natural Monuments and Geological Heritage, Lesvos, Greece. 3-7 October 2001. 